\title{
Applications for Gold-Base Brazing Alloys
}

\author{
M. M. Schwartz \\ Rohr Industries, Chula Vista, California
}

The advantageous properties of gold-based brazing alloys have found a number of uses in the construction of aero-engines and space craft, in nuclear engineering and in the electrical and electronic industries. After reviewing the characteristics of a number of commercially available brazing alloys this paper details some performance data that have governed the choice of alloy for specific applications.

Gold filler metals for brazing are being used at an increased rate every year, largely in the assembly of aircraft engine, aerospace and nuclear components. Some of their primary advantages are:

1. resistance to high temperature oxidation,

2. operating temperatures of $1000^{\circ} \mathrm{F}\left(538^{\circ} \mathrm{C}\right)$ or slightly over,

3. very little erosion attack to base metals (stainless steels, super alloys and refractory metals), and

4. free-flowing characteristics in hydrogen or vacuum brazing.

As a class they have better properties than the silver brazing alloys and they are without some of the deficiencies associated with the nickel alloy brazing materials.
In situations where intergranular penetration of the base metal cannot be tolerated, and where high strength and excellent oxidation resistance are required at temperatures around $1600^{\circ} \mathrm{F}\left(870^{\circ} \mathrm{C}\right)$, there is a strong interest in gold alloys. To be sure, the high gold content makes these alloys expensive on a per-ounce basis, but in most cases the value of the assembly and the extreme importance of reliable high-temperature performance outweigh by far the cost of the small amount of alloy needed to make the joint.

Compared with the high-nickel alloys, the gold alloys have lower hardnesses, better ductility and less tendency toward intergranular penetration. They can be produced in any variety of wrought forms, in

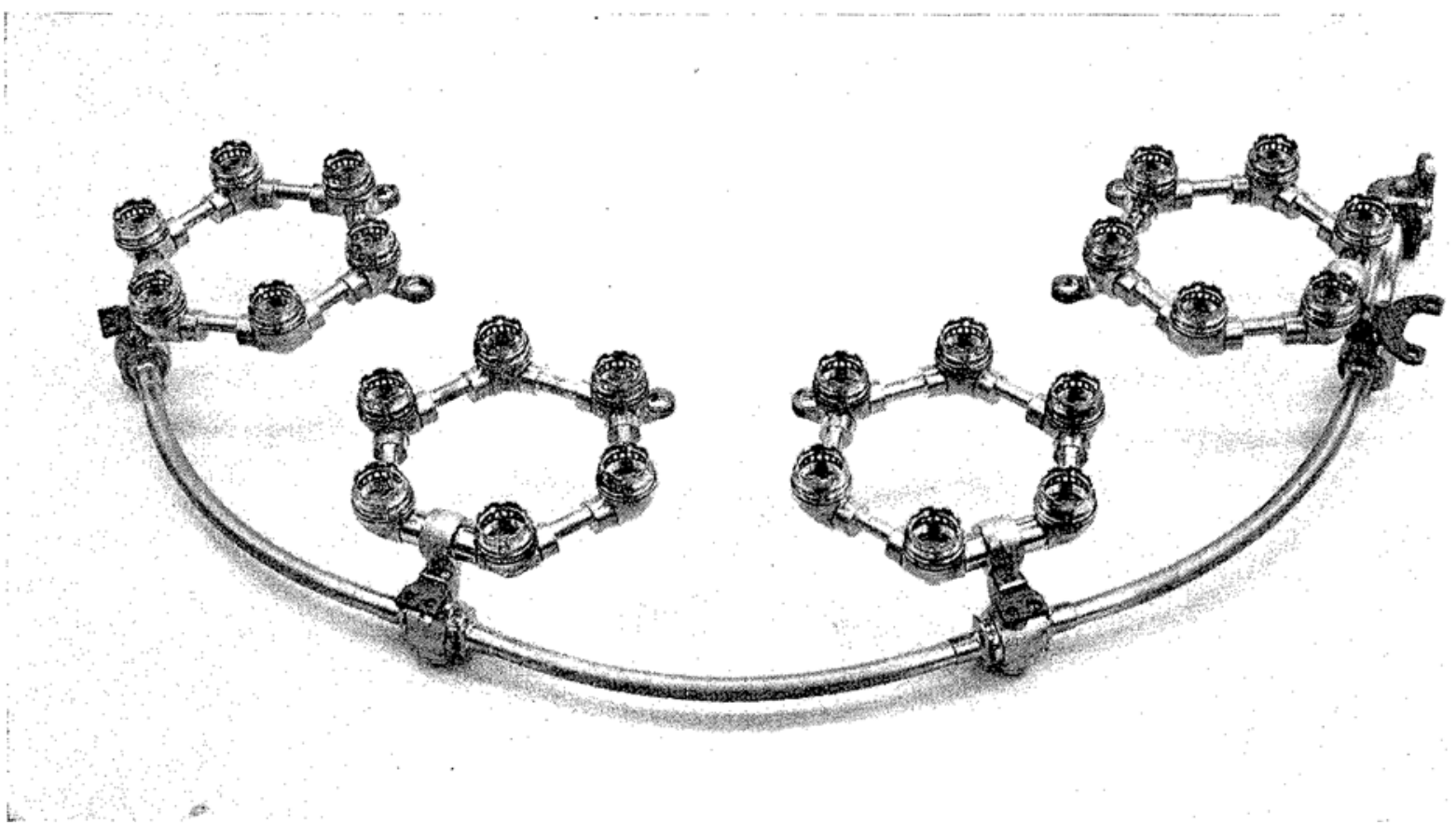

Fig. 1 A number of assemblies in aircraft engines, constructed in stainless steels and high temperature nickel-base alloys, are brazed with gold-based brazing alloys. This fuel manifold assembly from a Pratt and Whitney engine has been brazed with an 82 per cent gold-12 per cent nickel alloy 
Table 1

Industrial Gold Brazing Alloys

\begin{tabular}{|c|c|c|c|c|c|c|c|c|c|c|}
\hline \multirow[b]{2}{*}{ No. } & \multicolumn{6}{|c|}{ Composition, weight per cent } & \multicolumn{4}{|c|}{ Melting Range } \\
\hline & $\mathrm{Au}$ & $\mathrm{Cu}$ & $\mathrm{Ni}$ & $\mathrm{Ag}$ & $\mathrm{Pd}$ & Other & $\begin{array}{l}\text { Liqu } \\
{ }^{\circ} \mathrm{C}\end{array}$ & $\begin{array}{l}\text { dus } \\
{ }^{\circ} \mathrm{F}\end{array}$ & $\begin{array}{l}\text { Solid } \\
{ }^{\circ} \mathrm{C}\end{array}$ & lus \\
\hline 1 & 92 & & & & 8 & & 1240 & 2264 & 1200 & 2192 \\
\hline 2 & 50 & & 25 & & 25 & & 1121 & 2050 & 1102 & 2016 \\
\hline 3 & 35 & 62 & 3 & & & & 1030 & 1886 & 1000 & 1832 \\
\hline 4 & 82 & & 18 & & & & 950 & 1742 & 950 & 1742 \\
\hline 5 & 81.5 & 16.5 & 2 & & & & 925 & 1697 & 910 & 1670 \\
\hline 6 & 60 & 20 & & 20 & & & 845 & 1553 & 835 & 1535 \\
\hline 7 & 30 & & 36 & & 34 & & 1169 & 2136 & 1135 & 2075 \\
\hline 8 & 41 & & 22 & & 27 & $10 \mathrm{Cr}$ & 1110 & 2030 & 1054 & 1930 \\
\hline 9 & 70 & & 22 & & 8 & & 1037 & 1899 & 1005 & 1841 \\
\hline 10 & 20 & 78 & & & & $2 \ln$ & 1025 & 1877 & 975 & 1787 \\
\hline 11 & $35-$ & 65 & & & & & 1010 & 1850 & 990 & 1814 \\
\hline 12 & 37.5 & 62.5 & & & & & 1005 & 1841 & 985 & 1805 \\
\hline 13 & 40 & 60 & & & & & 1000 & 1832 & 980 & 1796 \\
\hline 14 & 72 & & 22 & & & $6 \mathrm{Cr}$ & 1000 & 1832 & 975 & 1787 \\
\hline 15 & 80 & 20 & & & & & 910 & 1670 & 908 & 1666 \\
\hline 16 & 60 & 37 & & & & $3 \ln$ & 900 & 1652 & 860 & 1580 \\
\hline 17 & 75 & 20 & & 5 & & & 895 & 1643 & 885 & 1625 \\
\hline 18 & 88 & & & & & $12 \mathrm{Ge}$ & 356 & 673 & 356 & 673 \\
\hline 19 & 50 & 50 & & & & & 970 & 1778 & 955 & 1751 \\
\hline 20 & 5 & & & & 20 & $75 \mathrm{Pt}$ & 1695 & 3083 & 1645 & 2993 \\
\hline 21 & 65 & & & & 35 & & 1440 & 2624 & 1428 & 2601 \\
\hline 22 & 75 & & & & 25 & & 1410 & 2570 & 1380 & 2516 \\
\hline 23 & 75 & & & & & $25 \mathrm{Pt}$ & 1410 & 2570 & 1210 & 2210 \\
\hline 24 & 87 & & & & 13 & & 1305 & 2381 & 1260 & 2300 \\
\hline 25 & 65 & & 35 & & & & 1075 & 1967 & 965 & 1769 \\
\hline 26 & 30 & 70 & & & & & 1035 & 1895 & 1005 & 1859 \\
\hline 27 & 32 & 65 & 3 & & & & 1025 & 1877 & 990 & 1814 \\
\hline 28 & 94 & 6 & & & & & 990 & 1814 & 965 & 1769 \\
\hline 29 & 51.7 & 45.5 & & 2.8 & & & 963 & 1765 & 924 & 1695 \\
\hline 30 & 58.3 & 39.6 & & 2.1 & & & 921 & 1690 & 906 & 1660 \\
\hline
\end{tabular}

contrast to nickel-boron-silicon alloys which are available only in powder tape, sintered powder, or cast forms. In addition, they have excellent wetting and flow characteristics.

\section{The Selection of Brazing Alloys}

Most of the commercially available brazing alloys listed in Table I contain gold, palladium and copper as their principal constituents. Several of the more prominent and widely used gold alloys are described in more detail below:

(1) 92 gold - 8 palladium is a very low vapour pressure, non-oxidisable alloy of palladium and gold which will wet and flow well on tungsten, molybdenum, stainless steel and nickel. Its low vapour pressure and high melting range make this alloy useful for brazing of cathode structures. (2) 50 gold -25 palladium -25 nickel is an alloy with excellent strength at elevated temperature. It wets and flows well on molybdenum, tungsten, stainless steel and nickel.

(3) 35 gold - 62 copper -3 nickel has better wetting and flow characteristics on iron alloys, nickel and molybdenum than the binary goldcopper alloys, and does not penetrate the grain boundaries of the glass sealing alloys such as Kovar and Rodar as readily; hence it is widely used for brazing these materials. It has a considerably 
smaller grain size, higher strength and is less subject to hydrogen embrittlement than the goldcopper alloys, thereby reducing the possibility of very slow "leaks" through the grain boundaries.

(4) 82 gold - 18 nickel is a very high strength alloy, possessing excellent corrosion resistance. Due to its favourable melting point and exceptional wetting and flow characteristics on tungsten, molybdenum and stainless steel, it is widely used for brazing these metals to copper, nickel and the glass sealing alloys, Kovar and Rodar. Because its solidus and liquidus are at the same temperature, this alloy is of particular value for brazing metals having widely different thermal expansions; for example, copper to Kovar or molybdenum. The alloy wets a wide range of high temperature iron- and nickel-base alloys such as the stainless steels, A286 (super iron-base alloy), and various Inconels very well. It does not alloy excessively with these materials, nor does it produce the severe intergranular penetration normally associated with the nickelbased brazing alloys containing boron. A minimum brazing temperature of $1800^{\circ} \mathrm{F}\left(982^{\circ} \mathrm{C}\right)$ is suggested for furnace brazing in hydrogen or dissociated ammonia having a $-40^{\circ} \mathrm{C}$ dew point or drier on 300 or 400 series stainless steels which do not contain additions of titanium or aluminium. Stainless steels of the 17-7 PH variety require dew points of $-70^{\circ} \mathrm{F}\left(-57^{\circ} \mathrm{C}\right)$ or drier for furnace brazing. Brazing has also been conducted in inert atmospheres and in vacuum. For torch brazing, protection with a high temperature flux is recommended. Where base metals containing elements which produce refractory oxides are encountered, such a flux with boron added will promote better wetting.

(5) 81.5 gold - 16.5 copper - 2 nickel was developed specifically to fill the need for a ductile, low vapour-pressure, non-silver-bearing alloy having a melting range below that of alloys 3 and 4 above. It has the excellent wetting and flow characteristics of No. 3 and, being far less brittle than the conventional 80 gold-20 copper alloy, it is there recommended as a replacement.

(6) 60 gold -20 copper -20 silver. Its low and very short melting range makes this alloy useful for brazing of components previously brazed with one of the higher melting alloys or for those applications in which higher brazing temperatures are undesirable.

(14) 72 gold - 22 nickel - 6 chromium is a hightemperature, gold-base brazing filler metal designed particularly for joining heat-resistant base metals where elevated temperature service is to be encountered. A minimum brazing temperature of $1950^{\circ} \mathrm{F}\left(1065^{\circ} \mathrm{C}\right)$ is recommended. This alloy wets a wide variety of heat-resistant base metals such as stainless steels, Hastelloys and René 41 and the brazing temperature is ideal for the solution heat treatment of René 41 . The alloy can also be used for brazing carbon, graphite and diamond.

This alloy is most commonly employed in very dry reducing or inert atmospheres or vacuum, but can be used in torch brazing with a high temperature flux (boron-modified). It is much less aggressive on many heat-resistant base metals than the high nickel-base filler metals containing chromium, silicon and boron.

\section{The Properties of Brazed Joints}

Results of limited short time elevated temperature tensile tests on Type 304 stainless steel butt joints using the 72 gold -22 nickel -6 chromium brazing alloy are as follows:

\begin{tabular}{|c|c|c|c|c|}
\hline \multicolumn{2}{|l|}{ T } & \multicolumn{3}{|c|}{ Tensile Strength } \\
\hline${ }^{\circ} \mathrm{F}$ & ${ }^{\circ} \mathrm{C}$ & (psi) & $\left(\mathrm{kg} / \mathrm{mm}^{2}\right)$ & $\left(\mathrm{N} / \mathrm{m}^{2}\right)$ \\
\hline Room & 20 & 62,000 & 45.3 & $4.3 \times 10^{8}$ \\
\hline 8 & 427 & 50,000 & 36.5 & $3.4 \times 10^{8}$ \\
\hline 1200 & 649 & 40,000 & 29.2 & $2.8 \times 10^{8}$ \\
\hline 1600 & 871 & 20,000 & 14.6 & $1.4 \times 10^{8}$ \\
\hline
\end{tabular}

Joints tested at the above temperatures, after seven days exposure to oxidising conditions at $1600^{\circ} \mathrm{F}$ $\left(871^{\circ} \mathrm{C}\right)$, showed virtually no loss in tensile strength. From an oxidation resistance standpoint this alloy is recommended for service temperatures up to $1500^{\circ} \mathrm{F}$ $\left(816^{\circ} \mathrm{C}\right)$.

Lap joints between Inconel and stainless steel, brazed in a helium atmosphere at $1900^{\circ} \mathrm{F}\left(1038^{\circ} \mathrm{C}\right)$ without flux, were exposed to air at $1600^{\circ} \mathrm{F}\left(871^{\circ} \mathrm{C}\right)$ for a period of 88 hours with no adverse effect. Photomicrographs of other joints in Inconel and stainless steel assemblies show only slight grain boundary attack in the stainless steel, but the extent was negligible considering the long brazing cycle employed. Nor was there any intergranular penetration in the Inconel part of the assembly.

This alloy is not recommended for brazing joints that may come in contact with liquid metals such as sodium and potassium which are used in some types of nuclear reactor heat exchangers.

The 82 gold -18 nickel joints provide much greater oxidation resistance than the silver-base brazing alloys and compare favourably in this respect to the nickel-silicon-boron and nickel-chromium-siliconboron brazing media. This alloy is also not recommended for applications involving contact with liquid metals such as sodium and potassium.

This alloy offers good room temperature strengths on stainless steels and results similar to those for 72 gold -22 nickel -6 chromium at limited short time elevated temperature tests can be obtained. 
Fig. 2 A stainless steel air duct, also from a Pratt and Whitney engine. The tubular assembly is brazed with a gold-nickel alloy

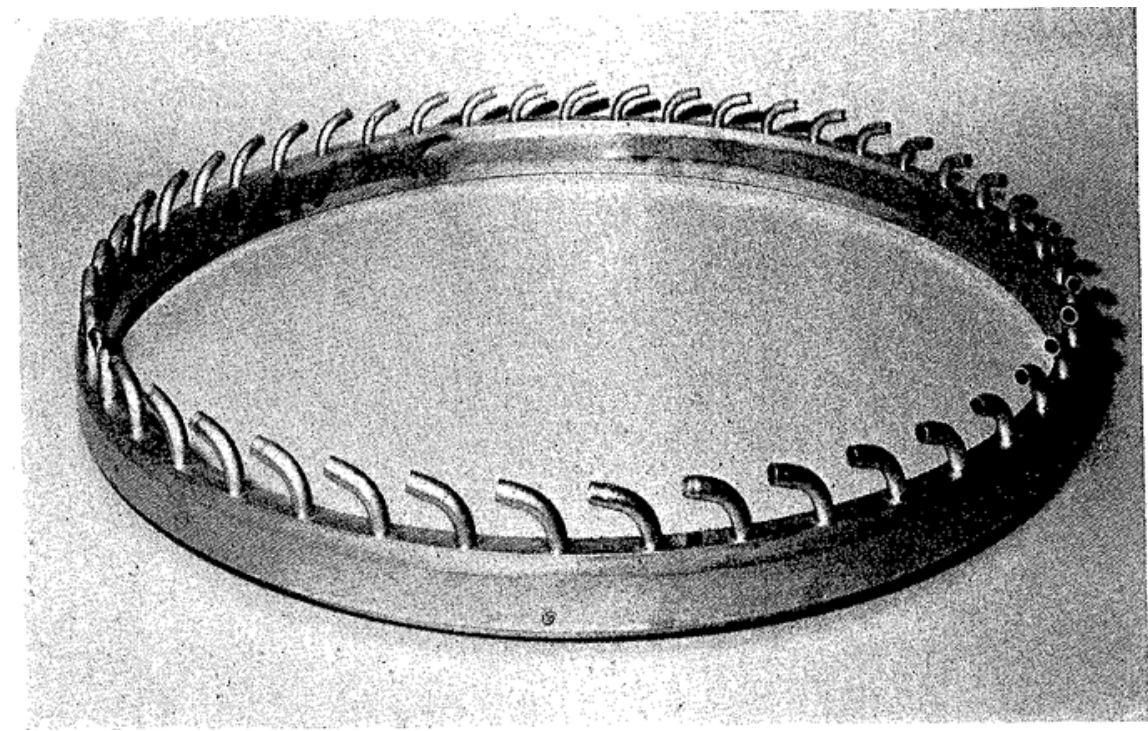

From an oxidation resistance standpoint, this alloy is recommended for service temperatures up to $1500^{\circ} \mathrm{F}\left(816^{\circ} \mathrm{C}\right)$.

From the previous data it can be concluded that the gold-base filler metals are used to produce strong ductile joints whose resistance to oxidation is considerably better than that which can be obtained with the silver-base filler metals. Chang (1) has investigated the room-temperature and elevated-temperature strength, ductility, impact properties and oxidation resistance of stainless steel joints brazed with goldbase and nickel-base filler metals. Sloboda (2), and Zimmerman and Colbus (3) have also concluded that joints made with the 82 gold- 18 nickel brazing alloy possessed excellent strength, ductility and oxidation resistance; however, the service temperature of $1500^{\circ} \mathrm{F}\left(816^{\circ} \mathrm{C}\right)$ for joints brazed with this filler metal is limited, since it melts at a relatively low temperature $\left(1742^{\circ} \mathrm{F}, 950^{\circ} \mathrm{C}\right)$. Other gold-base filler metals that can be used at considerably higher temperatures are shown in Table I (e.g. 92 gold-8 palladium, 75 gold- 25 platinum and others).

Fig. 3 High temperature operation, mechanical strength and economics have also determined the use of gold-nickel brazing alloys in the assembly of the vanes in aircraft engines
Some recently completed test work by an aircraft manufacturer on Inconel 718 relates to vane fabrication for engine components such as those shown in Figure 3. Excellent shear-tensile and rupture and fatigue results from room and elevated temperature testing of the 82 gold-12 nickel brazing alloy were obtained. The results of overlap shear-tensile tests in 0.032 inch Inconel 718 indicate the following; at room temperature shear load in ksi was 90.2 while at $800^{\circ} \mathrm{F}\left(427^{\circ} \mathrm{C}\right)$ the shear load was 58.6 and at $1200^{\circ} \mathrm{F}$ $\left(649^{\circ} \mathrm{C}\right)$ the tests showed $44.1 \mathrm{ksi}$. In overlap shear rupture of 0.032 inch Inconel 718 sheet at $1200^{\circ} \mathrm{F}$ $\left(649^{\circ} \mathrm{C}\right)$ all failures occurred in the braze joints with

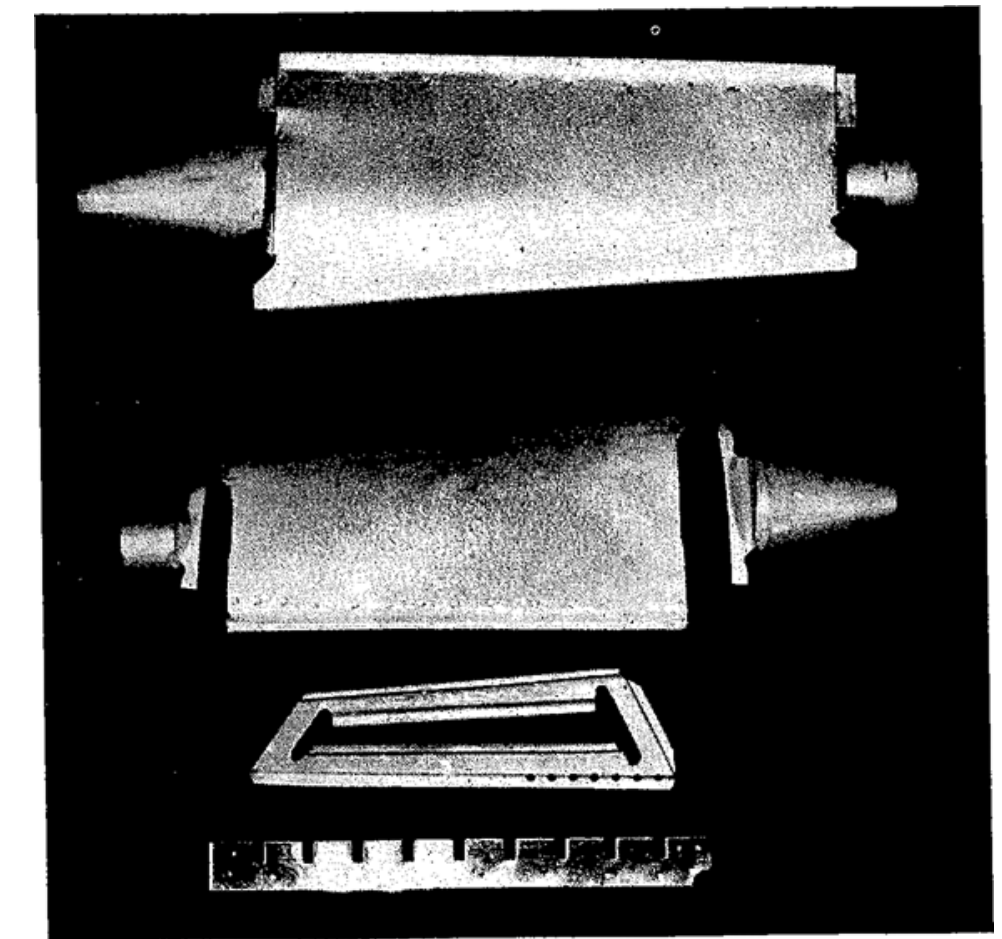




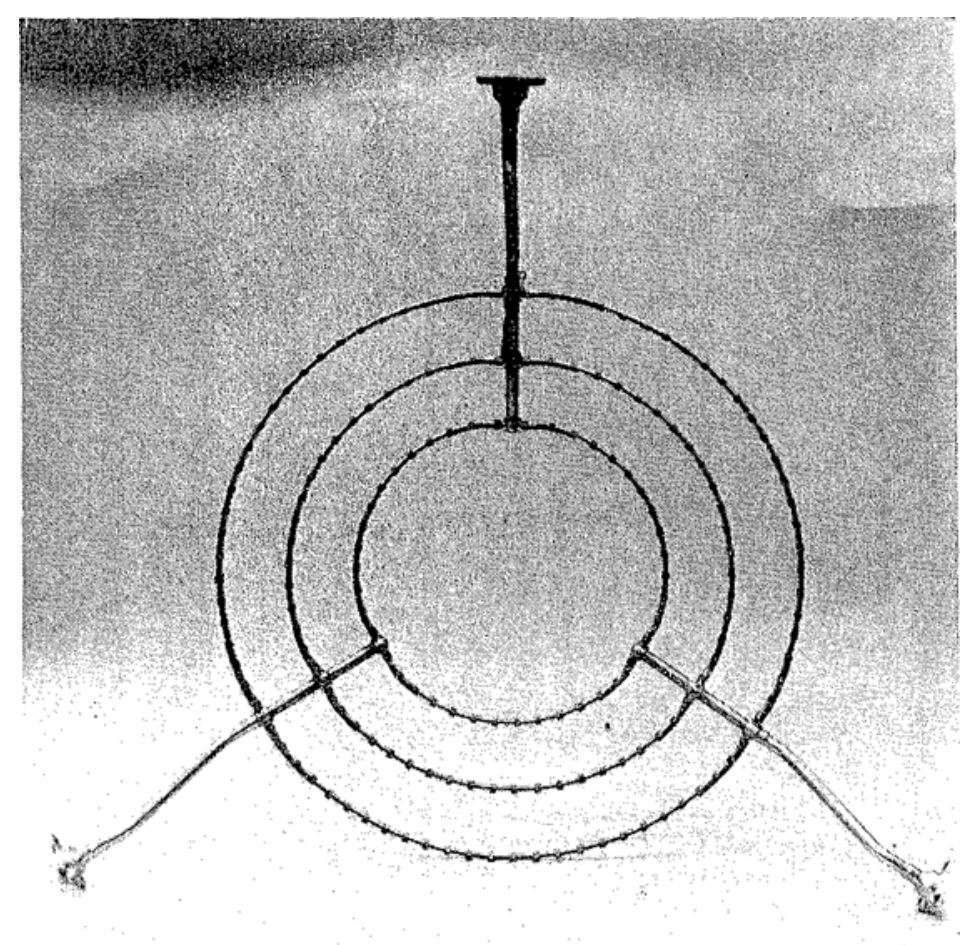

Fig. 4 A nickel alloy after-burner spray manifold with the hrazed fittings again assembled with 82 per cent gold -18 per cent nickel alloy by vacuum brazing

aircraft engines of today. Selected components of stainless steel and nickel-base superalloys have been utilised by Pratt \& Whitney in many aircraft in current service. In Figures 1,2 , and 4, are several of these components where temperatures, mechanical properties, and economics have dictated the use of the 82 gold-18 nickel braze alloy. All brazing of these components was performed in vacuum or in dry hydrogen.

\section{Aerospace Engineering}

To develop improved connectors for tubing, NASA researchers originated a diffusion bonding process that

joint stress running 5 to $8 \mathrm{ksi}$ and life in hours from 0.8 to 33.1 . Finally in $0.030 \mathrm{inch}$ Inconel 718 sheet at room temperature, high cycle fatigue in axial-axial mode showed failures occurring in the braze affected zone (failure in base metal through or adjacent to the fillet). The joint maximum stress $(A=0.95)$ in $\mathrm{ksi}$ ranged from 10 to 20 with a $2 \mathrm{~T}$ nominal overlap and the cycles ranged from 94 to $2263 \times 10^{3}$.

\section{General Uses and Applications}

The gold-copper alloys are the most widely used for brazing temperatures above the silver-copper alloy limits. They have good wetting action on premetallised ceramics. In joining electronic components, the various gold-copper brazing alloy compositions are used for step-brazing or where low vapour pressure alloys with higher brazing temperatures are required for service in vacuum applications. Steel, stainless steel, copper, copper alloys, nickel, and nickel alloys are readily brazed with gold-copper compositions. Most applications of these alloys are for controlled atmosphere procedures without use of a brazing flux. However, the alloys also are suitable for flux brazing. Gold-copper alloys with about 40 to 90 per cent gold are subject to ordering which reduces the ductility of the alloys. It is desirable to cool rapidly from $1000^{\circ} \mathrm{F}\left(538^{\circ} \mathrm{C}\right)$ to room temperature to obtain maximum ductility in the alloys.

\section{Aircraft Engines}

The 82 gold-18 nickel braze alloy has found numerous uses due to its excellent properties in the produced strong, leaktight joints (4). The process used an intermediate metal system of gold-coppergold to promote bonding. Bonding conditions of one hour at $500^{\circ} \mathrm{F}\left(260^{\circ} \mathrm{C}\right)$ with 30,000 psi $\left(21.9 \mathrm{~kg} / \mathrm{mm}^{2}\right.$ or $\left.2.07 \times 10^{8} \mathrm{~N} / \mathrm{m}^{2}\right)$ in air produced leaktight joints with bond tensile strengths greater than $20,000 \mathrm{psi}\left(14.6 \mathrm{~kg} / \mathrm{mm}^{2}\right.$ or $\left.1.38 \times 10^{8} \mathrm{~N} / \mathrm{m}^{2}\right)$. The research programme was conducted on connectors of Type 347 stainless steel (5).

The connector was pressurised to an internal pressure of $6000 \mathrm{psi}\left(4.4 \mathrm{~kg} / \mathrm{mm}^{2}\right.$ or $\left.4.14 \times 10^{7} \mathrm{~N} / \mathrm{m}^{2}\right)$ and leak-checked at room temperature and at $-320^{\circ} \mathrm{F}$ $\left(-196^{\circ} \mathrm{C}\right)$. No leaks were found with a leak detector that had a sensitivity of $10^{-7}$ atm $\mathrm{cm}^{3} / \mathrm{sec}$. The connector was then subjected to a vibration test of 200,000 cycles with a maximum fibre stress of $10,000 \mathrm{psi}\left(7.3 \mathrm{~kg} / \mathrm{mm}^{2}\right.$ or $\left.6.89 \times 10^{7} \mathrm{~N} / \mathrm{m}^{2}\right)$ at a rate of $87 \mathrm{cps}$. No leakage was detected during the test nor during a subsequent leak check with an internal pressure of $9000 \mathrm{psi}\left(6.6 \mathrm{~kg} / \mathrm{mm}^{2}\right.$ or $\left.6.20 \times 10^{7} \mathrm{~N} / \mathrm{m}^{2}\right)$.

The next test was a shock test designed to produce a maximum fibre stress of about $10,000 \mathrm{psi}(7.3 \mathrm{~kg}$ / $\mathrm{mm}^{2}$ or $\left.6.89 \times 10^{7} \mathrm{~N} / \mathrm{m}^{2}\right)$. The shock load was applied so as to introduce bending stresses across the joint. The test was made, but strain gauges attached to the connector showed that a $35,000 \mathrm{psi}(25.6 \mathrm{~kg}$ / $\mathrm{mm}^{2}$ or $2.14 \times 10^{8} \mathrm{~N} / \mathrm{m}^{2}$ ) fibre stress was produced. This was about three times the planned level and produced a leak in the bonded joint. However, the entire joint was not destroyed.

In a subsequent tensile test, a load of $15,200 \mathrm{ib}$ $\left(6.89 \times 10^{3} \mathrm{~kg}\right)$ was required to separate the connector. 
This is a stress of 9000 psi based on the initial bond area, but is about 15,000 psi $\left(10.95 \mathrm{~kg} / \mathrm{mm}^{2}\right.$ or $1.03 \times$ $10^{8} \mathrm{~N} / \mathrm{m}^{2}$ ) based on an estimate of the bonded area after the shock.

Since the actual bonds are formed between the intermediate materials, the bond system and bonding parameters should be satisfactory for the gold that can be electroplated. Since the joint is made in air, with low temperatures and with the bonding pressure produced by tightening the connector bolts, it should readily lend itself to use in field applications.

The gold-copper-nickel alloys are a modification of the gold-copper alloys with nickel to improve wetting. The nickel content increases the erosion of pre-metallised surfaces if temperature and brazing time are not properly controlled.

The ability of nickel to increase flow characteristics has led to the development of a family of gold-nickel brazing alloys. Probably the most popular of these during the past few years has been the 82 gold-18 nickel composition. This alloy has found wide usage in ceramic-to-metal joints, such as in electronic tubes.
Perhaps its most outstanding application to date has been its use by an aerospace company to join 304L corrosion-resistant tubular steel in the space programme's Lunar Excursion Module (LEM). More than 1000 joints, in various diameters and combinations were brazed on each LEM Reaction Control System used by the astronauts to manœuvre the craft.

\section{Nuclear Engineering}

The fabrication of heat exchangers for nuclear applications has been discussed by Slaughter et al. (6). These units were composed of a multitude of thinwalled, small-diameter Inconel 600 or Hastelloy $\mathrm{N}$ tubes assembled in suitable headers. The tube-toheader joints were welded with the gas tungsten-arc process, and back-brazed with 82 gold-18 nickel filler metals to reduce the notch at the root of the weld. This procedure prevented the formation of cracks that previously initiated at these notches during thermal cycling.

Table II

Room Temperature Tensile and Shear Strengths of Alloy 718 Joints made using various brazing joints alloys, brazing times and temperatures. 0.002 inch joint gap (Kirby and Hanks (7))

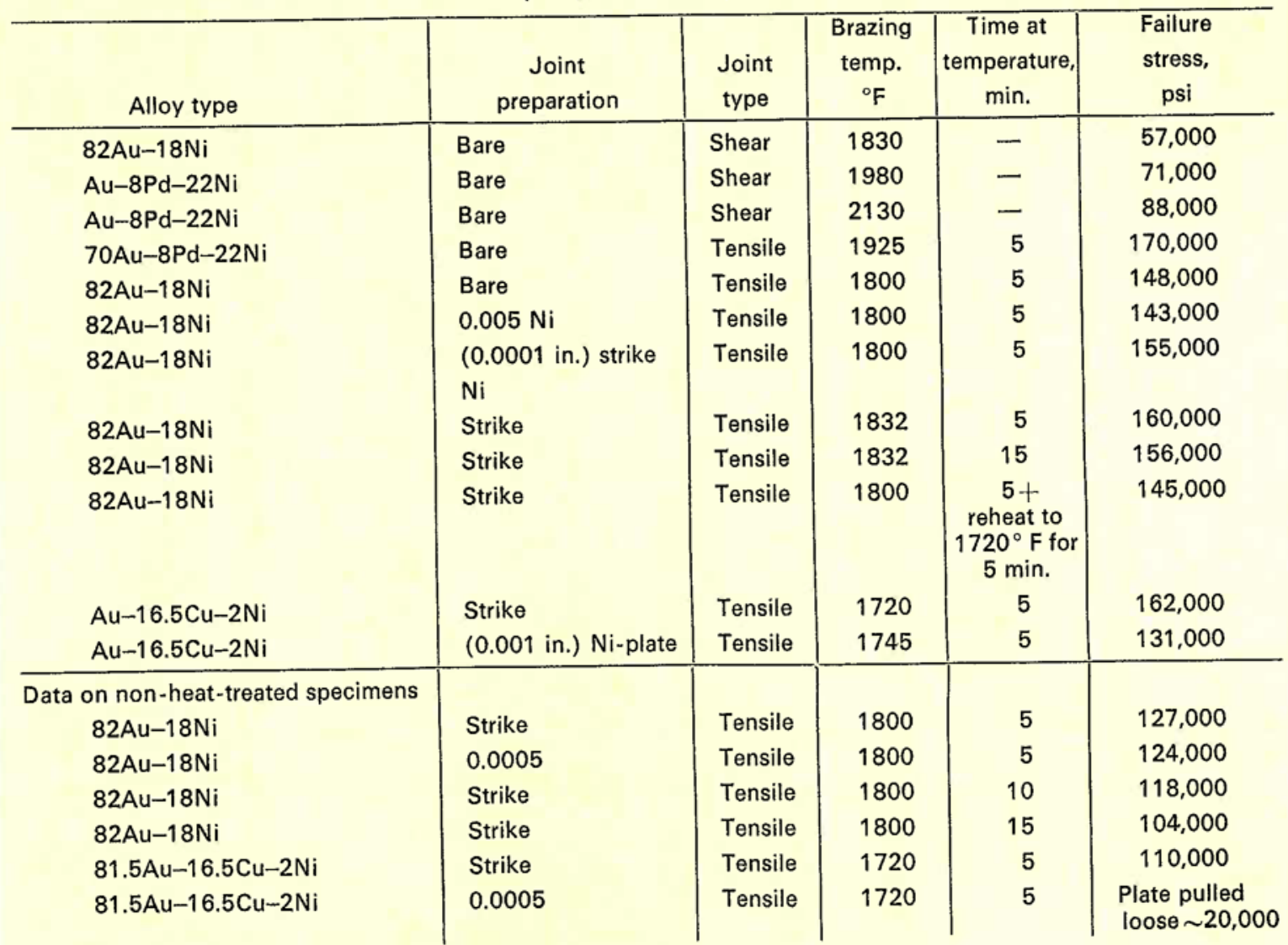


Kirby and Hanks (7) studied the brazing of Inconel 718 tubular assemblies for an application in the Phoebus-2A reactor. Nickel-base alloys containing boron and silicon were not considered for this application because of the high neutron capture crosssection of boron and of the possibility that boron and silicon would diffuse into the grain boundaries and reduce joint ductility. Also, the temperature required for brazing with nickel-base alloys might adversely affect the basis metal properties. For example, when Inconel 718 was heated above $1900^{\circ} \mathrm{F}\left(1038^{\circ} \mathrm{C}\right)$, there was a marked increase in grain size that resulted in reduced tensile and yield strengths. Several gold-base alloys were evaluated for this application. It was found that specimens could be brazed in a dry argon atmosphere if the combined content of water and oxygen did not exceed 2 p.p.m. (about $1 \times 10^{-3}$ torr). If the specimens were plated with nickel, good flow of the braze filler metal occurred in argon with impurity contents as high as 5 p.p.m. oxygen and 8 p.p.m. water. The 82 gold- 18 nickel alloy was selected for structural brazing applications on the basis of the data shown in Tables II and III.

\section{Brazing of Corrugated Panels}

In a recently completed programme by an aerospace firm, a series of corrugated L-605 cobalt-base superalloy panels was brazed with the 82 gold- 18 nickel braze alloy. One half of the test panels were subsequently diffusion-heat-treated to evaluate brazing versus diffusion. The tensile tests were performed at room temperature $\left(68^{\circ} \mathrm{F}\right.$ or $\left.20^{\circ} \mathrm{C}\right), 1000^{\circ} \mathrm{F}\left(538^{\circ} \mathrm{C}\right)$, and at $1200^{\circ} \mathrm{F}\left(649^{\circ} \mathrm{C}\right)$. Room temperature tests included the use of universal joints above and below the test specimens. Tests at elevated temperatures employed only one spherical joint below the test specimen to allow a limited universal effect and to minimise twisting and shearing of the samples during testing. The test rig is shown in Figure 6, and Table IV shows the tensile test data and bonding cycles for each specimen. Examination reveals that, for given test temperatures, diffusion-heat-treated samples exhibited higher ultimate loads than the brazed-only samples. The bond strengths of brazed-

Fig. 6 The elevated temperature test rig for tensile testing of gold alloy brazed corrugated panels made in a cobaltbase superalloy and brazed with a gold-nickel alloy in a cold wall vacuum furnace
Table III

Room Temperature Tensile Properties of Brazed and Heat Treated Alloy 718 Assemblies

(Kirby and Hanks (7))

\begin{tabular}{l|c|c|c|c}
\hline & $\begin{array}{c}\text { UTS } \\
\text { ksi }\end{array}$ & $\begin{array}{c}\text { Prop } \\
\text { Limit, } \\
\text { ksi }\end{array}$ & $\begin{array}{c}0.2 \% \\
\text { offet } \\
\text { yield } \\
\text { strength } \\
\text { ksi }\end{array}$ & $\begin{array}{c}\text { Total } \\
\text { permanent } \\
\text { elongation, } \\
\% \text { of total } \\
\text { length }\end{array}$ \\
\hline Group I & 190.7 & 83.2 & 152.6 & 13.4 \\
& 178.2 & 93.8 & 146.0 & 8.3 \\
\hline Group II & 188.7 & 113.0 & 165.9 & 8.7 \\
\hline & 207.9 & 124.7 & 175.7 & 10.4 \\
& 192.9 & 135.4 & 163.6 & 7.4 \\
& 206.3 & 136.8 & 169.9 & 15.2 \\
& 205.5 & 125.2 & 167.8 & 14.5 \\
& 205.4 & 120.8 & 166.8 & 13.4 \\
& 205.0 & 123.7 & 168.7 & 14.3
\end{tabular}

only samples decreased more rapidly with increasing temperatures than the bond strengths of diffusionheat-treated samples.

All of the brazed-only samples failed predominantly through the brazed joints. Diffusion-heat-treated

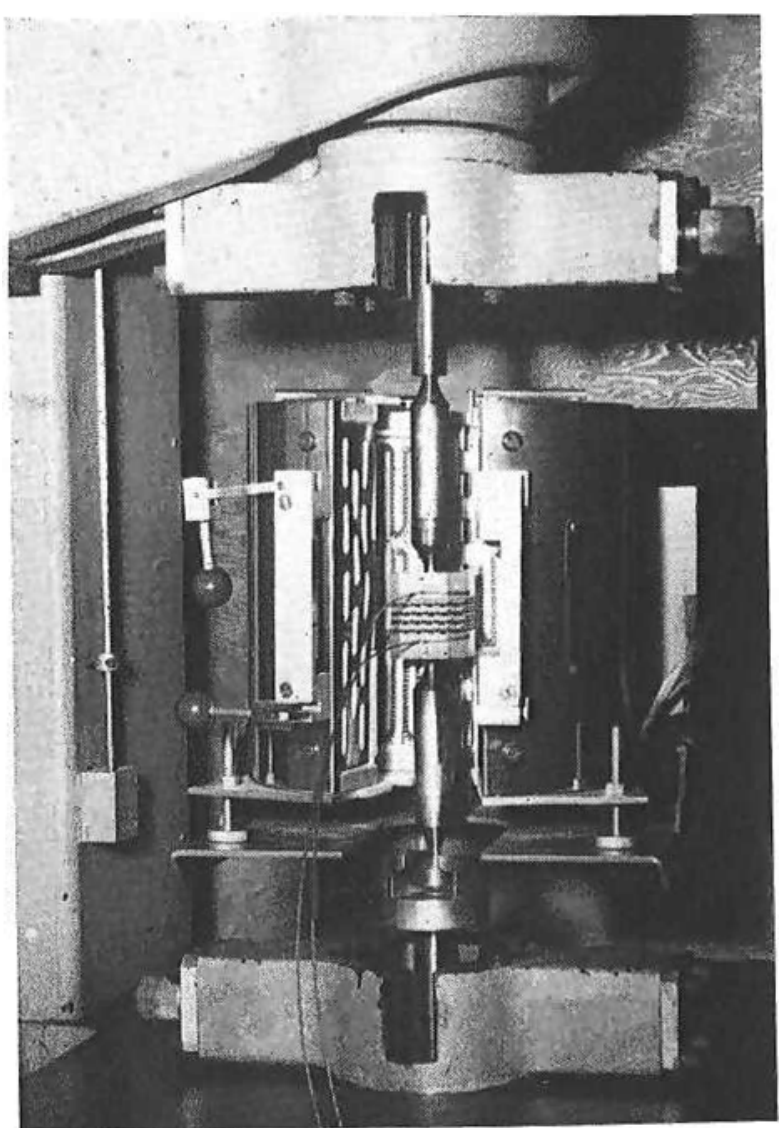


Table IV

Bonding Cycles and Ultimate Tensile Loads for Corrugated Sheet Specimens

\begin{tabular}{|c|c|c|c|c|c|c|}
\hline $\begin{array}{l}\text { Test } \\
\text { No. }\end{array}$ & Braze cycle & $\begin{array}{l}\text { Diffusion heat } \\
\text { treat cycle }\end{array}$ & $\begin{array}{l}\text { Tensile test } \\
\text { temperature }\end{array}$ & $\begin{array}{l}\text { Ultimate } \\
\text { (Pounds) }\end{array}$ & $\begin{array}{c}\text { Tensile } \\
\text { (kg) }\end{array}$ & $\begin{array}{l}\text { Load } \\
\text { (Newton) }\end{array}$ \\
\hline 1 & $\begin{array}{l}30 \mathrm{Min} \text { at } 1850^{\circ} \mathrm{F} \\
\left(1010^{\circ} \mathrm{C}\right)-30 \mathrm{psi}\end{array}$ & None & $1000^{\circ} \mathrm{F}\left(538^{\circ} \mathrm{C}\right)$ & 2,643 & 1199 & 11757 \\
\hline 2 & $\begin{array}{l}30 \mathrm{Min} \text { at } 1850^{\circ} \mathrm{C} \\
\left(1010^{\circ} \mathrm{C}\right)-30 \mathrm{psi}\end{array}$ & None & Ambient $\left(20^{\circ} \mathrm{C}\right)$ & 5,060 & 2295 & 22508 \\
\hline 3 & $\begin{array}{l}30 \mathrm{Min} \text { at } 1850^{\circ} \mathrm{F} \\
\left(1010^{\circ} \mathrm{C}\right)-30 \mathrm{psi}\end{array}$ & None & $1200^{\circ} \mathrm{F}\left(649^{\circ} \mathrm{C}\right)$ & 1,923 & 872 & 8554 \\
\hline 4 & $\begin{array}{l}30 \mathrm{Min} \text { at } 1850^{\circ} \mathrm{F} \\
\left(1010^{\circ} \mathrm{C}\right)-30 \mathrm{psi}\end{array}$ & $6 \mathrm{~h}$ at $2000^{\circ} \mathrm{F}\left(1094^{\circ} \mathrm{C}\right)$ & Ambient $\left(20^{\circ} \mathrm{C}\right)$ & 5,175 & 2347 & 23020 \\
\hline 5 & $\begin{array}{l}30 \mathrm{Min} \text { at } 1850^{\circ} \mathrm{F} \\
\left(1010^{\circ} \mathrm{C}\right)-30 \mathrm{psi}\end{array}$ & $6 \mathrm{~h}$ at $1950^{\circ} \mathrm{F}\left(1066^{\circ} \mathrm{C}\right)$ & $1000^{\circ} \mathrm{F}\left(538^{\circ} \mathrm{C}\right)$ & 3,143 & 1426 & 13981 \\
\hline 6 & $\begin{array}{l}30 \mathrm{Min} \text { at } 1850^{\circ} \mathrm{F} \\
\left(1010^{\circ} \mathrm{C}\right)-30 \mathrm{psi}\end{array}$ & $4 \mathrm{~h}$ at $2050^{\circ} \mathrm{F}\left(1121^{\circ} \mathrm{C}\right)$ & $1200^{\circ} \mathrm{F}\left(649^{\circ} \mathrm{C}\right)$ & 2,714 & 1231 & 12072 \\
\hline
\end{tabular}

samples failed only in the base metal sheet at room temperature, through the joints and through the L605 sheet at $1000^{\circ} \mathrm{F}\left(538^{\circ} \mathrm{C}\right)$, and predominantly through the bonded joints at $1200^{\circ} \mathrm{F}\left(649^{\circ} \mathrm{C}\right)$.

Stress levels were not obtained because the crosssectional areas of the test specimens were not readily calculated and because all of the specimens exhibited a tendency to twist and to fail in shear. It was estimated that diffusion-heat-treated specimens experienced substantially higher stress levels than brazed-only specimens at $1000^{\circ} \mathrm{F}\left(538^{\circ} \mathrm{C}\right)$ and less.

Metallographic examinations of brazed-only samples showed the gold alloy filler to be generally confined to the brazed joints themselves. Diffusion heat treated specimens exhibited gold alloy filler on all sheet surfaces and penetration of the alloy as deep as 0.005 in. $(0.113 \mathrm{~mm})$ into the base metal sheet near bonded joints.

Coffey (8) also investigated the use of gold-base brazing alloys 82 gold-18 nickel and 72 gold-22 nickel-6 chromium for fabricating Inconel 718 honeycomb structures.

\section{The Brazing of Graphite}

Alloys in the gold-nickel-molybdenum ternary system have been developed and found satisfactory to braze graphite to graphite joints. Alloys in the system containing low percentages of molybdenum can be used for graphite to molybdenum joints, whereas alloys with greater percentages of this carbide former can be used to braze graphite-tographite joints as well.

Alloys in the gold-nickel-tantalum system have also been developed that have satisfactorily flowed on graphite. Compositions suitable for brazing graphite to graphite joints ( 60 gold-10 nickel-20 tantalum) sometimes exhibited fillet cracking, but compositions containing lower percentages (less than approximately 30 weight per cent) of tantalum have been satisfactory for brazing graphite to metal joints.

The 35 gold- 35 nickel- 30 molybdenum alloy is especially attractive, for it can be used to braze both graphite to graphite and graphite to metal joints with high integrity. It is attractive as a general-purpose alloy and, in addition, it posseses good corrosion resistance to molten fluoride salts. It can be used to braze both low and high porosity grades of graphite in which the joints have strengths at least as great as that of the graphite (9).

\section{In Electrical Construction}

A brazing alloy for nickel, with a brazing temperature range from 1680 to $1720^{\circ} \mathrm{F}$ (916 to $938^{\circ} \mathrm{C}$ ), has been developed and used for brazing of nickelclad silver electrical conductors operating at $1200^{\circ} \mathrm{F}$ $\left(649^{\circ} \mathrm{C}\right)$. The alloy composition is 77.9 gold- 17.1 nickel-5 indium.

This alloy was developed for brazing the ends of nickel-clad silver stator coils in an electromagnetic boiler feed pump which operates with a hot spot temperature of $1200^{\circ} \mathrm{F}\left(649^{\circ} \mathrm{C}\right)$. The operating environment prohibited the presence of silver either in the brazed joint or on open surfaces within the pump. Therefore the brazing filler metal could not contain silver, and the brazing temperature was kept below the melting point of the conductive silver cores to prevent alloying with the braze metal. To prevent corrosion by residual flux, no flux was used in the brazing operation.

A review of brazing filler metals and techniques 
indicated the need for a gold-base alloy and brazing in an inert gas atmosphere.

Available gold-nickel alloys met the requirements except for their high melting points. A review of additives for the depression of melting points resulted in the selection of indium. Indium has good solubility with both gold and nickel, and the liquidus temperatures of gold-indium and nickel-indium binary systems can be substantially reduced by small increases in the indium content. The low content of indium in the selected brazing filler metal minimises the effect of indium's high vapour pressure. This brazing alloy may be used in high temperature electrical systems in lieu of conventional goldnickel, gold-copper or silver brazing filler metals; it has low electrical resistivity, does not require a flux, and is less corrosive than other gold-nickel and gold-copper alloys.

\section{The Future}

The gold-nickel and gold-copper brazing alloys have found wide usage in the aerospace, nuclear and electronics industries. This is based on the enviable properties that these alloys exhibit. The gold-nickel alloy has a sharp solidus/liquidus transition; both gold-nickel and gold-copper have reasonable flow in varying gap situations without excessive "flashing"; both have strength and ductility, and the goldnickel alloy possesses good resistance to oxidation at elevated temperatures.

Thus the gold-base brazing alloys are widely used and have been able to fill an important gap in the brazing alloy spectrum.

\section{References}

1 W. H. Chang, "Further Evaluation of Ni-Cr-B and Au$18 \mathrm{Ni}$ Brazing Alloys", Welding 7., 1958, 37, (12), $535 \mathrm{~S}$ $542 \mathrm{~S}$

2 M. H. Sloboda, "Industrial Gold Brazing Alloys", Gold Bull., 1971, 4, (1), 2-8

3 J. Colbus and K. F. Zimmerman, "Properties of GoldNickel Alloy Brazed Joints in High Temperature Materials", Gold Bull., 1974, 7, (2), 42-49

4 "Precious Metals Boost Brazing Uses," Welding Eng., $1970,38-41$

5 P. A. Kammer, R. E. Monroe and D. C. Martin, "Further Studies of Diffusion Bonding below $1000^{\circ} \mathrm{F}$," Welding $\mathcal{F}$., $1969,48,(3), 116 S-124 S$

6 G. M. Slaughter, E. A. Franco-Ferreira and P. Patriarca, "Welding and Brazing of High Temperature Radiators and Heat Exchangers," Welding $\mathcal{F}$., 1968, 47, (1), 15-22

7 R. S. Kirby and G. S. Hanks, "Brazing of NickelChromium Alloy 718," Welding f., 1968, 47, (3), 97 S$105 \mathrm{~S}$

8 F. J. Coffey, "Shear Strength of Brazed Inconel 718," Final Report No. A252, Aeronautical Systems Division, Air Force Systems Command, Wright-Patterson Air Force Base, Ohio, Contract No. AF33(657)-11215, January 1963

9 R. G. Donnelly and G. M. Slaughter, "The Brazing of Graphite,"Welding 7., 1962, (5), 461-469

\section{Gold Inlaid Contacts in New Edge Connectors}

Already established with a range of interconnection systems, Texas Instruments has now introduced a new series of printed circuit edgeboard connectors in which a hard gold inlay is confined to the actual contact area.

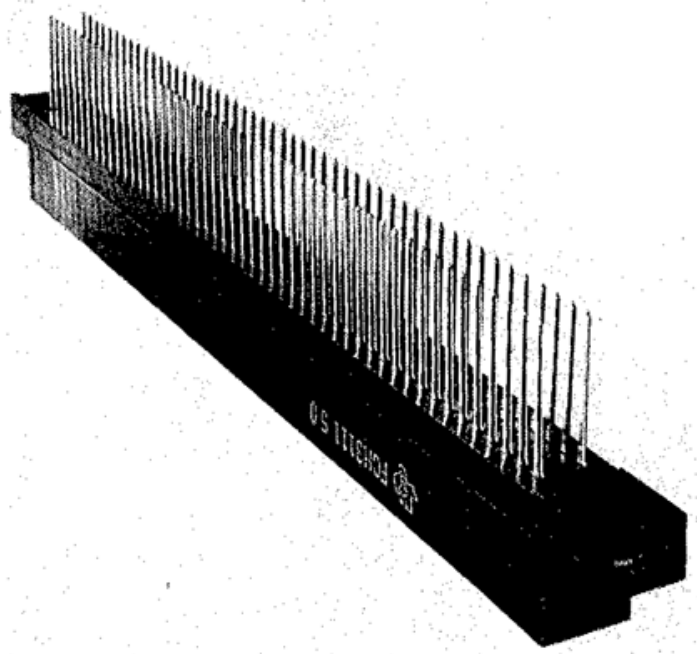

Thirty standard types based upon 0.100 inch and 0.125 inch centres, in both wire wrapped and solder tail pin construction, have been made available to meet commercial applications.

The use of the gold inlay technique as opposed to gold plating for the contacts enables a relatively thick layer of gold to be located only where it is needed-where low contact resistance and good wearing properties are essential. The spring material used is a corrosion resistant copper alloy containing 9 per cent nickel and 2 per cent tin, and in the course of manufacturing the strip a continuous narrow stripe of a hardened gold alloy is inlaid and firmly bonded to the base metal along its base and edges. The thickness of the gold alloy is roo microinches, and the inlay technique eliminates wastage of gold.

Texas Instruments is one of the leading producers of bi-metals for contacts and other purposes at its main plant in Attleboro, Massachusetts. This technique makes it possible to select any desired combination of width and thickness of gold or gold alloy inlay, and to produce more than one stripeor stripes on both faces-in a base metal alloy for contact purposes. 